Original Article

\title{
Biochemical composition of some Echinodermata (Holothuroidea, Echinoidea) from the Red Sea, Egypt
}

\author{
Composição bioquímica de alguns Echinodermata (Holothuroidea, Echinoidea) do Mar \\ Vermelho, Egito
}

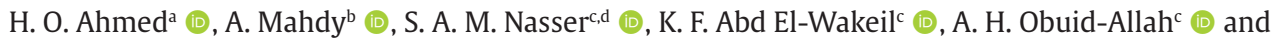 \\ M. M. Hassan ${ }^{\mathrm{e}, \mathrm{f} *}$ (D)
}

aNational Institute of Oceanography and Fisheries, Kayet Bey, Alexandria, Egypt

${ }^{\mathrm{b} A l-A z h a r}$ University, Faculty of Science, Department of Zoology, Assiut Branch, Egypt

'Assiut University, Faculty of Science, Department of Zoology, Assiut, Egypt

dAden University, Faculty of Education, Department of Biology, Aden, Yemen

eTaif University, Faculty of Science, Department of Biology, Taif, Saudi Arabia

fAin Shams University, Faculty of Science, Zoology Department, Cairo, Egypt

\begin{abstract}
In the present study, the biochemical composition of some Echinodermata (Holothuroidea, Echinoidea) from the Red Sea, Egypt was investigated. The results showed that the highest percentage of saturated fatty acids (SFA) was in Holothuria nobilis and the lowest percentage was recorded in Holothuria scabra. The highest percentage of monounsaturated fatty acids (MUFA) was recorded in Pearsonothuria graeffei while the lowest percentage was recorded in Holothuria atra. The highest percentage of polyunsaturated fatty acids (PUFA) was recorded in Holothuria nobilis and the lowest percentage was recorded in Holothuria atra. The highest percentage of omega-3 fatty acids was recorded in Stichopus hermanni however, the lowest percentage was recorded in Diadema setosum. The highest percentage of omega- 6 fatty acids was recorded in Bohadschia vitiensis where, the lowest percentage was recorded in Holothuria atra. In addition, nonessential amino acid (NEAA) glycine were the highest in all species and serine was the lowest while Essential amino acid (EAA) arginine was the highest and cysteine was the lowest. All of the NEAA recorded highest concentrations in S. hermanni except proline. The recorded essential amino acids were histidine, isoleucine, phenylalanine, and leucine. The latter was high in Pearsonothuria graeffei. Tyrosine, valine, threonine, and arginine were high in Stichopus hermanni. The present study proved that sea cucumbers has great nutritional value.
\end{abstract}

Keywords: amino acids, fatty acids, Red Sea, Holothuria, Pearsonothuria, Diadema, Bohadschia, Stichopus.

\begin{abstract}
Resumo
No presente estudo, investigou-se a composição bioquímica de algumas espécies Echinodermata (Holothuroidea, Echinoidea) do Mar Vermelho no Egito. Os resultados mostraram que a maior porcentagem de ácidos graxos saturados (SFA) foi na espécie Holothuria nobilis e a menor porcentagem foi registrada em Holothuria scabra. A maior porcentagem de ácidos graxos monoinsaturados (MUFA) foi registrada na espécie Pearsonothuria graeffei, enquanto a menor porcentagem foi registrada em Holothuria atra. O maior percentual de ácidos graxos poliinsaturados (PUFA) foi registrado em Holothuria nobilis e o menor percentual foi registrado em Holothuria atra. A maior porcentagem de ácidos graxos ômega-3 foi registrada na espécie Stichopus hermanni, entretanto, a menor porcentagem foi registrada em Diadema setosum. A maior porcentagem de ácidos graxos ômega- 6 foi registrada em Bohadschia vitiensis e a menor porcentagem foi registrada em Holothuria atra. Além disso, o nível de aminoácido não-essencial (NEAA) glicina foi o mais alto em todas as espécies e o de serina foi o mais baixo, enquanto o nível de aminoácido essencial (EAA) arginina foi o mais alto e a cisteína foi o mais baixo. Todos os NEAA registraram concentrações mais altas em S. hermanni, exceto prolina. Os aminoácidos essenciais registrados foram histidina, isoleucina, fenilalanina e leucina. A leucina apresentou alto nível na espécie Pearsonothuria graeffei. Tirosina, valina, treonina e arginina apresentaram níveis elevados em Stichopus hermanni. Assim, o presente estudo comprovou que o pepino-do-mar possui grande valor nutricional.
\end{abstract}

Palavras-chave: aminoácidos, ácidos graxos, Mar Vermelho, Holotúria, Pearsonotúria, Diadema, Bohadschia, Stichopus.

*e-mail: montasermohamed@sci.asu.edu.eg; m.sayd@tu.edu.sa

Received: December 6, 2020 - Accepted: April 6, 2021 


\section{Introduction}

Extracts of marine invertebrates especially echinoderms attained intensive investigatory activities due to their nutritive and benifets for human health (Katanaev et al., 2019; Luparello et al., 2019). Many studies have demonstrated the consumption of fresh or dried food of sea cucumber and sea urchins. Consumption methods vary from country to country. In Japan, the body wall of sea cucumber is eaten raw while it is grilled in New Guinea (Preston, 1993). On the other hand, the body wall in living sea cucumber has the ability of regeneration and therefore is used in wound healing (Fredalina et al., 1999). Sea cucumbers is known to have aphrodisiac power (Singh, 1980). Holothurin or saponins (triterpene glycosides) is a biological active compound found in sea cucumbers (Nigrelli, 1952; Yamanouchi, 1955). This compound is used in the treatment of Hypertntion, gastric ulcer and asthma (Kaswandi et al., 1993; Ridzwan et al., 1995, 2014; Hasan et al., 1996). Saponins were also used to kill protozoans and molluscs, have an analgesic, antinociceptive, antioxidant activity, to impair the digestion of protein, to cause hypoglycemia and to act as antifungal and antiviral agent (Francis, et al., 2002; Desai et al., 2017).

Sea urchins are important elements of many cuisines. Approximatly 50,000 tons of sea urchins are captured every year. Sea urchin's gonads are consumed especially in France, Japan and Peru. Their taste is soft, melting and sweet like fruit. Their quality is indicated by the colour, which ranges from light yellow to bright orange. Some species of sea cucumbers and sea urchins are medically important where some species produce toxins that have pharmaceutical uses in medical purposes (Mona et al., 2012; Raghunathan et al., 2013; Katanaev et al., 2019; Luparello et al., 2019; Chen et al., 2020).

After the depletion of natural stocks in many localtion, Egypt has become one of the most important sea cucumber suppliers (Lovatelli et al., 2004). Sea cucumber is considered as nonpopular food and not favorable for most people in Egypt. The Egyptian sea cucumber has very low content of fats while having high protein and carbohydrates content. This is why it is suggested as a source of food in Egypt especially Actinopyga mauritiana that contains high protein content and Holothuria scabra which is rich in omega-6. In addition, the bioactive compounds of sea cucumber are highely efficent in treating inflammatory diseases, tissue regeneration, and suggested to be important food for patients with hyperlipidemia (Omran, 2013)

Some compounds have antimicrobial activity or act as anti-inflammatory agents. Some other species are commercially important as food delicacy in the oriental region. They are considered as a multimillion-dollar industry that processes and sells the body wall and gonads. However, the high value of such species along with the ease of their collection from shallow water and their top-heavy age structures all lead to the collapse and overexploitation their natural populations as well as the depletion of their fisheries in some regions (Mona et al., 2012; Raghunathan et al., 2013; Katanaev et al., 2019; Luparello et al., 2019; Chen et al., 2020).

\section{Materials and Methods}

\subsection{Collection of Echinoderm specimens}

Sea cucumbers and sea urchins spacemens were collected from different sites of the Red Sea, Egypt. Holothuria scabra, Pearsonothuria graeffei, Stichopus hermanni, and Diadema setosum were collected from the shorefront of the National Institute of oceanography and fisheries, Hurghada branch. Holothuria atra and Holothuria nobilis were collected from 17 $\mathrm{km}$ south Safaga City in the front of the mangrove protected area. Holothuria leucospilota and Bohadschia vitiensis were collected from El-Hamrawein harbor (20 km north of AlQusier City). Echinometra mathaei was collected from Ras Gharib shore. Samples were collected by snorkeling and SCUBA diving (15m maximum depth).

Samples for biochemical preparations had small parts of the tissue cut off. Tissues of sea cucumber and sea urchin were immediately frozen in liquid nitrogen in the field and later transferred to $\mathrm{a}-80^{\circ} \mathrm{C}$ freezer.

\subsection{Biochemical analysis}

Biochemical analysis were done for nine echinoderm species; seven species of sea cucumbers namely (Holothuria atra, Holothuria nobilis, Holothuria leucospilota, Holothuria scabra, Bohadschia vitiensis, Pearsonothuria graeffei, Stichopus variegatus) and two species of sea urchins (Diadema setosum, Echinometra mathaei).

\subsection{Fatty acid analysis}

\subsubsection{Gas liquid chromatographic techniques}

The animals were cleaned and dissected to remove the visceral organs and body fluid before homogenization. Lipids from sea cucumbers and sea urchins species were extracted separately. After phase equilibration, the lower chloroform layer (TL) was removed and dried in a rotary vacuum evaporator at $32{ }^{\circ} \mathrm{C}$. The extracted lipids were redissolved in chloroform/methanol (9:1, v/v) and finally stored at $0{ }^{\circ} \mathrm{C}$ until used (Bligh and Dyer, 1959).

The following conditions were used in gas liquid chromatography for analysis of oil subfraction of n-hexane fraction using FID detector. The column used was a capillary column ( $30 \mathrm{~m}$ x $250 \mathrm{~mm} \times 0.25 \mu \mathrm{m}$ ) and packed with DB-5 (5\% Phenyl, 95\% Methyl polysiloxane). The injected volume was $1 \mu \mathrm{l}$. The analysis was carried out at a programmed temperature. The initial temperature was $40^{\circ} \mathrm{C}$ increasing $10{ }^{\circ} \mathrm{C} / \mathrm{min}$ to $150{ }^{\circ} \mathrm{C}$ for $3 \mathrm{~min}$ then $10^{\circ} \mathrm{C} / \mathrm{min}$ to $220^{\circ} \mathrm{C}$ for $6 \mathrm{~min}$ then $15^{\circ} \mathrm{C} / \mathrm{min}$ to $280{ }^{\circ} \mathrm{C}$ for $28 \mathrm{~min}$. Run Time 61 min, 2 min (Post Run) $260{ }^{\circ} \mathrm{C}$, Flow Program $0.5 \mathrm{~mL} / \mathrm{min}$ for $10.9 \mathrm{~min}$ then $1 \mathrm{~mL} / \mathrm{min}$ per $\mathrm{min}$ to $1 \mathrm{~mL} / \mathrm{min}$ for 30 min GC-MS (7890A-5975B).

\subsection{Amino acids content}

The acid hydrolyzed amino acids by amide bound breakage were determined according to (Pellet and Young, 1980).

\subsubsection{Reagents}

- Diethyl ether (for defatting process); 
- $6 \mathrm{~N} \mathrm{HCl}$ (515.46 mL from $\mathrm{HCl} 36 \%$ was completed to $1000 \mathrm{~mL}$ bidistilled water);

- Bidistilled water.

\subsubsection{Procedures}

For each dry sample of the present echinoderms, $1 \mathrm{~g}$ was defatted using diethyl ether and $0.4 \mathrm{~g}$ was hydrolyzed in sealed evacuated pyrex test tube using $5 \mathrm{~mL}$ of $6 \mathrm{~N}$ hydrochloric acid at $110{ }^{\circ} \mathrm{C}$ for 24 hrs. At the end of the period, hydrolysate from each sample was transferred quantitavely to containers and the hydrochloric acid was then evaporated to dryness at $50-60{ }^{\circ} \mathrm{C}$ in water bath. Distilled water $(5 \mathrm{~mL})$ was added to each hydrolysate and then evaporated to dryness to remove the remins of hydrochloric acid, this process was repeated one more time. Then samples were dried until to dry film was obtained. The dry film was dissolved in a known volume of dilution buffer ( $0.1 \mathrm{~N}$ sodium acetate buffer, $\mathrm{Ph} 2.2$ ) and the solution was filtered through $0.45 \mathrm{~mm}$ membrane filter and the samples were stored frozen in sealed vials until fractionation of the amino acids by the amino acid analyzer (LC 3000 Eppendorf, Central Lab of Desert Research Center).

\section{Result}

\subsection{Fatty acids}

\subsubsection{Saturated Fatty Acids (SFA)}

The present study showed the fatty acids contents in the nine echinoderm species Table 1 . The saturated C: 16 fatty acid composition was the highest (28.68\%) in Holothuria nobilis and the lowest (8.63\%) was in H. scabra. A high overall mean was recorded for all species $(21.82 \pm 6.97 \%)$. The C:21 fatty acid content showed the lowest percentage range ( $1.06 \%$ in H. atra to $7.96 \%$ in Diadema setosum), and a low overall mean was recorded for all species (approximately $4.62 \pm 2.41 \%$ ). The highest percentage of saturated fatty acids was recorded in $H$. nobilis (81.25\%), and the lowest percentage was recorded in $H$. scabra (28.06\%). The overall mean across all studied species was $55.29 \pm 15.82 \%$.

\subsubsection{Monounsaturated fatty acids (MUFA)}

Regarding to monounsaturated fatty acids, C:18 fatty acid content was the highest (42.99\%) in Pearsonothuria. graeffei and the lowest (8.72\%) in H. atra, the high overall mean for all species was $(27.31 \pm 11.48 \%)$. The $\mathrm{C}: 20$ fatty acid content showed the lowest percentage range $(0.00 \%$ in $H$. leucospilota to $7.96 \%$ in D. setosum), and a low overall mean was recorded across all species (approximately $3.62 \pm 2.65 \%$ ). The highest percentage of monounsaturated fatty acids (MUFA) was recorded in P. graeffei (47.96\%), while the lowest percentage was recorded in $\mathrm{H}$. atra (13.23\%). The overall mean for all studied species was $30.93 \pm 12.09 \%$.

\subsubsection{Polyunsaturated fatty acids (PUFA)}

The sea cucumber $H$. nobilis showed the highest percentage of polyunsaturated C: 18 fatty acid (17.71\%) and the lowest (4.72\%) in Holothuria atra, and a high overall mean was recorded for all species $(10.58 \pm 4.17 \%)$. The $\mathrm{C}: 20$ fatty acid content showed the lowest percentage range $(0.00 \%$ in Bohadschia vitiensis to $6.09 \%$ in Stichopus hermanni), and a low overall mean was recorded for all species ( $3.42 \pm 1.87 \%$ ). The highest percentage of polyunsaturated fatty acids was recorded in $H$. nobilis (20.59\%), and the lowest percentage was recorded in $\mathrm{H}$. atra (7.85\%). The overall mean for all species was $14 \pm 5.02 \%$.

\subsubsection{Omega-3 fatty acids}

The percentage of $\mathrm{C}: 16$ fatty acid was the highest (16.28\%) in D. setosum and the lowest $(4.28 \%)$ in H. scabra, and a high overall mean was recorded for all species $(10.7 \pm 4.08 \%)$. The $\mathrm{C}: 29$ fatty acid content showed the lowest percentage range $(0.00 \%$ in $H$. atra, H. leucospilota, B. vitiensis, Echinometra mathaei, and D. setosum to $5.72 \%$ in P. graeffei), and a low overall mean was recorded for all species (1.42 $\pm 2.08 \%$ ). The highest percentage of omega-3 fatty acids was recorded in S. hermanni (43.91\%), and the lowest percentage was recorded in D. setosum (24.06\%). The overall mean for all species was $30.62 \pm 6.87 \%$.

\subsubsection{Omega-6 fatty acids}

The echinoderm $D$. setosum recorded the highest percentage of C:16 fatty acid content (4.85\%) while the lowest $(0.00 \%)$ was in $H$. leucospilota. The high overall mean was recorded for all species $(1.41 \pm 1.39 \%)$. The content of C:22 fatty acid showed the lowest percentage range $(0.00 \%$ in $H$. leucospilota, E. mathaei and D. setosum to $2.46 \%$ in $B$. vitiensis), and a low overall mean for all species was recorded (approximately $0.91 \pm 0.97 \%$ ). The highest percentage of omega- 6 fatty acids was recorded in B. vitiensis (8.23\%), and the lowest percentage was recorded in $H$. atra (4.76\%). The overall mean for all species was $8.35 \pm 2.88 \%$ (Table 1 ).

\subsection{Amino acids}

Table 2 shows the amino acids profile in the in nine investigated echinoderms which contains a total of 6 nonessential amino acids (NEAA) and 10 essential amino acids (EAA). All of the NEAA were found in high concentrations in S. hermanni except for proline. Glycine (GLY) and glutamine (GLU) had the highest concentrations among the NEAA (121.59 and $90.77 \mathrm{mg} / \mathrm{g}$ ) respectively in S. hermanni. The concentration of proline was the highest in $H$. atra (41.11 mg/g). The overall mean among all species was the highest for GLY $(65.84 \pm 32.41)$ and the lowest was for serine (14.14 \pm 1.98$)$. The concentrations of NEAA were low in E. mathaei.

Essential amino acids were found in higher concentrations in some species than others. histidine, isoleucine, phenylalanine, and leucine were found in high concentrations (17.47, 18.43, 21.99 and $25.89 \mathrm{mg} / \mathrm{g}$ ) respectively in $P$. graeffei. However, in $S$. hermanni was having high concentrations of tyrosine, valine, threonine, arginine (14.96, 22.99, 29.28 and $74.34 \mathrm{mg} / \mathrm{g}$ ) respectively. Methionine was in high concentration $(8.38 \mathrm{mg} / \mathrm{g})$ in $H$. leucospilota; while cysteine concentration was high in H. scabra (7.74 mg/g). The overall mean of arginine for all 
Table 1. Fatty acids profile in nine echinoderm species, (percentage, mean and standard deviation (SD))

\begin{tabular}{|c|c|c|c|c|c|c|c|c|c|c|c|}
\hline$\stackrel{\Xi}{\Xi}$ & 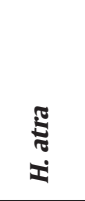 & 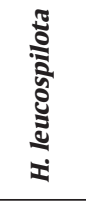 & $\begin{array}{l}\vdots \\
\vdots \\
\vdots \\
\vdots\end{array}$ & 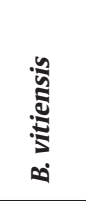 & 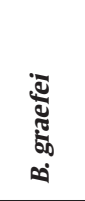 & $\begin{array}{l}\tilde{\Xi} \\
\mathbb{\Xi} \\
\mathbf{\Xi} \\
\mathbf{\Xi} \\
\text { v }\end{array}$ & 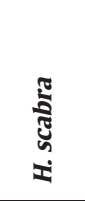 & 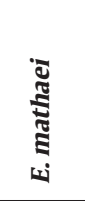 & 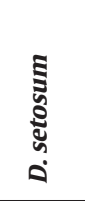 & 芯 & 命 \\
\hline C:16 & 28.17 & 17.2 & 28.68 & 26.82 & 24.08 & 27.75 & 8.63 & 16.26 & 18.75 & 21.82 & 6.97 \\
\hline C:17 & 0.33 & 5.07 & 13.83 & 13.89 & 8.74 & 10.91 & 5.97 & 7.78 & 11.91 & 8.71 & 4.47 \\
\hline C:18 & 9.29 & 2.48 & 9.29 & 7.16 & 3.44 & 3.58 & 6.58 & 1.29 & 4.61 & 5.3 & 2.91 \\
\hline C:19 & 0.33 & 5.07 & 13.83 & 0 & 8.74 & 10.91 & 0 & 7.78 & 0 & 5.18 & 5.37 \\
\hline C:20 & 4.51 & 4.64 & 7.61 & 2.51 & 4.97 & 6.61 & 2.71 & 3.44 & 7.96 & 4.99 & 2.01 \\
\hline $\mathrm{C}: 21$ & 1.06 & 4.68 & 7.61 & 2.51 & 4.97 & 6.61 & 2.71 & 3.44 & 7.96 & 4.62 & 2.41 \\
\hline $\mathrm{C}: 27$ & 4.01 & 0 & 0.4 & 2.94 & 1.78 & 0.89 & 1.46 & 26.41 & 4.1 & 4.67 & 8.29 \\
\hline Total SFA & 47.71 & 39.14 & 81.25 & 55.84 & 56.72 & 67.26 & 28.06 & 66.4 & 55.28 & 55.29 & 15.82 \\
\hline C:18 & 8.72 & 35.61 & 33.79 & 21.22 & 42.99 & 27.87 & 17.12 & 19.15 & 39.33 & 27.31 & 11.48 \\
\hline C:20 & 4.51 & 0 & 0.41 & 2.51 & 4.97 & 6.61 & 2.71 & 2.93 & 7.96 & 3.62 & 2.65 \\
\hline Total MOFA & 13.23 & 35.61 & 34.19 & 23.74 & 47.96 & 34.48 & 19.83 & 22.08 & 47.29 & 30.93 & 12.09 \\
\hline C:18 & 4.72 & 11.65 & 17.71 & 9.69 & 11.67 & 12.39 & 6.13 & 6.89 & 14.37 & 10.58 & 4.17 \\
\hline $\mathrm{C}: 20$ & 3.13 & 5.98 & 2.87 & 0 & 3.25 & 6.09 & 2.14 & 3.24 & 4.09 & 3.42 & 1.87 \\
\hline Total PUFA & 7.85 & 17.63 & 20.59 & 9.69 & 14.92 & 18.48 & 8.27 & 10.14 & 18.46 & 14 & 5.02 \\
\hline C:14 & 1.46 & 0 & 2.4 & 1.54 & 1.35 & 10.91 & 1.42 & 6.45 & 4.44 & 3.33 & 3.44 \\
\hline C:16 & 10.81 & 14.75 & 6.62 & 15.26 & 9.58 & 8.38 & 4.28 & 10.35 & 16.28 & 10.7 & 4.08 \\
\hline $\mathrm{C}: 20$ & 5.35 & 0 & 4.58 & 7.18 & 3.22 & 12.7 & 3.23 & 3.29 & 2.35 & 4.66 & 3.61 \\
\hline C:23 & 3.82 & 0.5 & 1.09 & 0 & 1.88 & 5.34 & 1.43 & 0.51 & 0 & 1.62 & 1.83 \\
\hline $\mathrm{C}: 24$ & 0.35 & 6.26 & 0 & 0 & 0 & 0 & 0 & 6.45 & 0.98 & 1.56 & 2.74 \\
\hline $\mathrm{C}: 27$ & 11.35 & 12.63 & 4.9 & 9.88 & 9.98 & 3.7 & 13.57 & 0 & 0 & 7.33 & 5.28 \\
\hline $\mathrm{C}: 29$ & 0 & 0 & 0.86 & 0 & 5.72 & 2.9 & 3.33 & 0 & 0 & 1.42 & 2.08 \\
\hline Omega-3 & 33.15 & 34.14 & 20.45 & 33.86 & 31.72 & 43.91 & 27.25 & 27.04 & 24.06 & 30.62 & 6.87 \\
\hline C:14 & 0.35 & 6.27 & 0 & 0 & 0 & 0 & 0 & 5.24 & 0 & 1.32 & 2.53 \\
\hline C:16 & 1.96 & 0 & 1.2 & 0.98 & 0.94 & 1.13 & 0.6 & 1.07 & 4.85 & 1.41 & 1.39 \\
\hline $\mathrm{C}: 20$ & 0.84 & 0 & 3.73 & 2.33 & 1.61 & 0 & 1.61 & 1.79 & 0 & 1.32 & 1.26 \\
\hline C:21 & 1.53 & 0 & 1.89 & 2.46 & 1.69 & 1.01 & 1.4 & 0 & 0 & 1.11 & 0.92 \\
\hline $\mathrm{C}: 22$ & 0.07 & 0 & 1.89 & 2.46 & 1.69 & 0.68 & 1.42 & 0 & 0 & 0.91 & 0.97 \\
\hline C:31 & 0 & 4.79 & 0.4 & 0 & 2.63 & 0.89 & 3.48 & 0 & 0 & 1.35 & 1.82 \\
\hline C:34 & 0 & 0 & 1.47 & 0 & 4.59 & 2.2 & 0 & 0 & 0 & 0.92 & 1.60 \\
\hline Omega-6 & 4.76 & 11.06 & 10.57 & 8.23 & 13.15 & 5.91 & 8.51 & 8.1 & 4.85 & 8.35 & 2.88 \\
\hline
\end{tabular}

species was the highest $(24.98 \pm 17.79)$ and cysteine was the lowest for $(2.38 \pm 2.86)$.

\section{Discussion}

The present study evaluated the nutrition value of nine echinoderm species by studying their amino acids and fatty acids content. The results showed species specific variations in amino acids and fatty acids concentrations. Previous studies indicated that the chemical composition and proximate analysis of sea cucumbers and sea urchins may differ among species and among members of the same species from different regions (Wang et al., 2009).

This work indicated that the studied species are particularly rich in total saturated fatty acid (SFA) and monounsaturated fatty acids (MUFA) especially Holothuria scabra and Holothuria nobilis and Pearsonothuria graeffei. This result is in agreement with that reported by Yahyavi et al. (2012) while higher concenterations were reported by Ridzwan et al. (2014). The higher content of C: 16 fatty acid and C: 18 PUFA in Holothuria nobilis than in Holothuria scabra, and the lower content of both C: 18 MUFA and C: 18 PUFA in Holothuria atra was in contradiction with 
Table 2. Concentrations of essential (EAA) and nonessential (NEAA) amino acids in nine echinoderm species (percentage, mean and standard deviation (SD)).

\begin{tabular}{|c|c|c|c|c|c|c|c|c|c|c|c|}
\hline 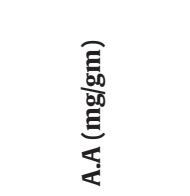 & 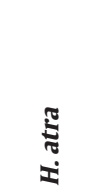 & 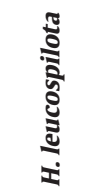 & 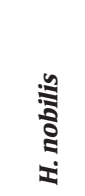 & 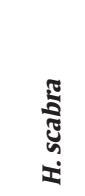 & 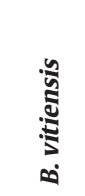 & 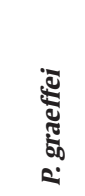 & 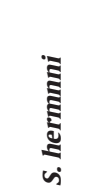 & 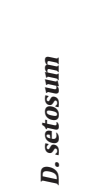 & 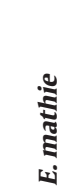 & $\sum^{\Xi}$ & कิ \\
\hline \multicolumn{12}{|c|}{ NEAA } \\
\hline Serine & 13.39 & 15.04 & 11.85 & 13.37 & 13.14 & 16 & 18.56 & 13.78 & 12.15 & 14.14 & 2.10 \\
\hline Glutamine & 69.71 & 70.03 & 52.95 & 60.47 & 63.06 & 49.33 & 90.77 & 43.68 & 37.32 & 59.7 & 16.18 \\
\hline Proline & 41.11 & 51.93 & 29.57 & 38.56 & 27.41 & 15.15 & 37.69 & 15.93 & 12.46 & 29.98 & 13.55 \\
\hline Glycine & 80.52 & 103.3 & 71.25 & 73.71 & 59.54 & 22.79 & 121.59 & 38.96 & 20.9 & 65.84 & 34.38 \\
\hline Alanine & 39.52 & 52.9 & 37.9 & 39.82 & 35.96 & 26.91 & 71.41 & 23.24 & 15.08 & 38.08 & 16.64 \\
\hline Aspartic acid & 45.61 & 43.37 & 36.49 & 42.45 & 45.25 & 43.46 & 68.19 & 38.78 & 34.33 & 44.21 & 9.81 \\
\hline \multicolumn{12}{|c|}{ EAA } \\
\hline Threonine & 19.88 & 19.96 & 14.47 & 16.18 & 20.14 & 20.13 & 29.28 & 18.2 & 15.84 & 19.34 & 4.30 \\
\hline Cysteine & 5.82 & 4.13 & 0 & 7.74 & 0 & 0 & 0 & 0 & 3.75 & 2.38 & 3.04 \\
\hline Valine & 15.64 & 22.24 & 13.31 & 16.07 & 15.4 & 22.08 & 22.99 & 17.57 & 16.5 & 17.98 & 3.54 \\
\hline Methionine & 3.62 & 8.38 & 3.4 & 4.72 & 4.96 & 7.49 & 6.74 & 5.9 & 6.33 & 5.73 & 1.70 \\
\hline Isoleucine & 9.64 & 13.12 & 7 & 9.88 & 11.95 & 18.43 & 13.95 & 14.99 & 14.08 & 12.56 & 3.39 \\
\hline Leucine & 14.18 & 19.24 & 13.33 & 15.38 & 17.84 & 25.89 & 23.47 & 20.78 & 19.37 & 18.83 & 4.19 \\
\hline Tyrosine & 6.73 & 9.75 & 7.07 & 5.9 & 8.01 & 9.46 & 14.96 & 8.97 & 7.24 & 8.68 & 2.69 \\
\hline Phenylalanine & 9.32 & 17.79 & 10.74 & 8.17 & 14.03 & 21.99 & 21.84 & 16.42 & 12.74 & 14.78 & 5.10 \\
\hline Histidine & 9.04 & 10.68 & 6.23 & 8.19 & 8.27 & 17.47 & 12.62 & 10.28 & 14.09 & 10.76 & 3.47 \\
\hline Arginine & 15.66 & 24.34 & 20.57 & 23.25 & 21.04 & 15.92 & 74.34 & 14.51 & 15.17 & 24.98 & 18.87 \\
\hline
\end{tabular}

the results of Ridzwan et al. (2014) who found other three species containing high amounts of C: 16 fatty acids namely: Holothuria scabra, Holothuria leucospilota and Holothuria atra. Polyunsaturated fatty acids and monounsaturated fatty acids have grate importance for human health. These results are in line with previous studies conducted Romashina (1983), Svetashev et al. (1991) and Aydin et al. (2011). However, in the present study the total MUFA and PUFA were lower than that reported by Wen et al. (2010). Ridzwan et al. (2014) recorded higher values of PUFA while MUFA was lower compared with the present study. PUFA content is one of the vital aspects used to determinethe food quality. The high content of PUFA in the studied echinoderms suggest a higher activity of their biosynthetic system (Sushchik et al., 2003). Furthermore, Long-chain n-3 PUFA play major role in physiological processes of human body (Brett and Müller-Navarra, 1997). furthermore, sea cucumbers species are rich in glycosides containing triterpene or steroide copounds thet are anticancer and antitumurs (Katanaev et al., 2019; Luparello et al., 2019) and improves carbohydrate metabolism in insulin resitant patients (Chen et al., 2020).

The value of Omega-3 in the present study was lower than that reported by Yahyavi et al. (2012). This is normal where it differs even in the same species from different localities (Wang et al., 2009) due to the environmental and nutritional factors. The present study was done in the Red
Sea with special seasonal temperature that may reflect the difference in the Omega concentration. Differences in the fatty acid content in sea cucumbers depend on their environmental conditions, in particular the temperature of water, which influence the composition of fatty acid (Aydin et al., 2011).The difference of fatty acid content may be related to the feeding habit of sea cucumbers, as they differs in their sediment uptake. Holothurians contain high levels of fatty acids due to their feeding on on bottom sediments. This is why the fatty acid profiles of Holothuria scabra and $H$. leucospilota are of major interest. High levels of branched chain fatty acids are known to be found in the sediments as mentioned by Leo and Parker (1966), Sargent et al. (1983), Phillips (1984) and Dunstan et al. (1988). It is believed that marine organisms have more fatty acids of the $\omega-3$ series than freshwater organisms (Ackman, 1967). The results of this study showed highcontents of fatty acids, especially $\omega$-3-series MUFA in Stichopus hermanni (43.91\%), which are vital fatty acids in human food, with a high level of total PUFA found in all specimens; these echinoderms were used in traditional medicin and food sublements (Bahrami and Franco, 2016). Furthermore, the results are in agreement with those from previous studies such as Yahyavi et al. (2012).

In the present work, all of the echinoderm species showed high levels of glycine, which is in agreement with the results of other studies such as Wen et al. (2010), 
Bordbar et al. (2011), Omran (2013) and Haider et al. (2015). All the studied species considered as source of glycine where it helps in the creation of muscle tissues and conversion of glucose to energy. Moreover, intake of glycine before bedtime improve sleeping (Yamadera et al., 2007; Liu et al., 2017).

The sea cucumber Stichopus hermanni had the highest amounts of amino acids among the investigated species however, the sea urchin Echinometra mathaei had the lowest values. In Malaysia, S. hermanni is considered as a traditional remedy for hypertension. The present study showed that the content of essential amino acid (EAA) was lower than the content of nonessential amino acid (NEAA), which agrees with Omran (2013). Amino acids are considered as stress response indicators and have a vital role in controlling oxidative stress (Matés et al., 2002). Worldwide, sixty six commercial sea cucumber species are exploited to date (Purcell, 2010). Since the 1990s, small scale fisheries of sea cucumber started in Egypt; fishermen collecte them and processe meat for export to Singapore and Hong Kong (Lawrence et al., 2004).

\section{Conclusion}

Marine animals especially invertebrates are rich in natural compounds of both commercial and medical importance such as food supplements, and therabiotic usage. There are a lot of unexploited marine invertebrates having a lot of economic and social benefits as food sources, anti-cancer, anti-microbial, anti-inflamatory, antioxidants and immunomodulatory agents.

The present work spread the light to magnify the utilization from the marine invertebrate treasury to improve the socio-economic outcome.

\section{Acknowledgements}

The authors of this work deeply appreciate the deanship of scientific research for funding this work by researchers supporting Project number (TURSP-2020/119), Taif University, Saudi Arabia.

\section{References}

ACKMAN, R.G., 1967. Fatty acids of coho salmon fingerlings. Journal of the American Oil Chemists' Society, vol. 44, no. 6, pp. 372. http://dx.doi.org/10.1007/BF02582663.

AYDIN, M., SEVGILI, H., TUFAN, B., EMRE, Y. and KÖSE, S., 2011. Proximate composition and fatty acid profile of three different fresh and dried commercial sea cucumbers from Turkey. International Journal of Food Science E Technology, vol. 46, no. 3, pp. 500-508. http://dx.doi.org/10.1111/j.1365-2621.2010.02512.x.

BAHRAMI, Y. and FRANCO, C.M.M., 2016. Acetylated triterpene glycosides and their biological activity from Holothuroidea reported in the past six decades. Marine Drugs, vol. 14, no. 8, pp. 147-184. http://dx.doi.org/10.3390/md14080147. PMid:27527190.

BLIGH, E.G. and DYER, W.J., 1959. A rapid method of total lipid extraction and purification. Canadian Journal of Biochemistry and
Physiology, vol. 37, no. 8, pp.911-917. http://dx.doi.org/10.1139/ 059-099. PMid:13671378.

BORDBAR, S., ANWAR, F. and SAARI, N., 2011. High value components and bioactives from sea cucumbers for functional foods - a review. Marine Drugs, vol. 9, no. 10, pp. 1761-1805. http:// dx.doi.org/10.3390/md9101761. PMid:22072996.

BRETT, M.T. and MÜLLER-NAVARRA, N., 1997. The role of highly unsaturated fatty acids in aquatic food web processes. Freshwater Biology, vol. 38, no. 3, pp. 483-499. http://dx.doi. org/10.1046/j.1365-2427.1997.00220.x.

CHEN, Y., WANG, Y., YANG, S., YU, M., JIANG, T. and LV, Z., 2020. Glycosaminoglycan from apostichopus japonicas improves glucose metabolism in the liver of insulin resistant mice. Marine Drugs, vol. 18, no. 1, pp. 1-14. http://dx.doi.org/10.3390/ md18010001.

DESAI, D., RAORANE, C., PATIL, S., GADGIL, R. and PATKAR, D., 2017. Anacardium occidentale: Fountain of phytochemicals: The qualitative profiling. World J Pharmaceut Res, vol. 6, no. 5, pp. 585-592.

DUNSTAN, G.A., SINCLAIR, A.J., O'DEA, K. and NAUGHTON, J.M., 1988. The lipid content and fatty acid composition of various marine species from southern Australian coastal waters. Comparative Biochemistry and Physiology Part B: Comparative Biochemistry, vol. 91, no. 1, pp. 165-169. http://dx.doi.org/10.1016/03050491(88)90130-7.

FRANCIS, G., KEREM, Z., MAKKAR, H.P. and BECKER, K., 2002. The biological action of saponins in animal systems: a review. British Journal of Nutrition, vol. 88, no. 6, pp. 587-605. http:// dx.doi.org/10.1079/BJN2002725. PMid:12493081.

FREDALINA, B.D., RIDZWAN, B.H., ABIDIN, A.A.Z., KASWANDI, M.A., ZAITON, H., ZALI, I., KITTAKOOP, P. and JAIS, A.M.M., 1999. Fatty acid compositions in local sea cucumber, Stichopus chloronotus, for wound healing. General Pharmacology: The Vascular System, vol. 33, no. 4, pp. 337-340. http://dx.doi.org/10.1016/S03063623(98)00253-5. PMid:10523072.

HAIDER, M.S., SULTANA, R., JAMIL, K., TARAR, O.M. and AFZAL, W., 2015. A study on proximate composition, amino acid profile, fatty acid profile and some mineral contents in two species of sea cucumber. Journal of Animal and Plant Sciences, vol. 25, no. 1, pp. 168-175.

HASAN, Y.N., YEAP, K.H. and SHAHIMI, M.M., 1996. Effect of sea cucumber water extract on systemic anaphylactic reaction. The Malaysian Journal of Medical Sciences, vol. 3, suppl., pp. 37-38.

KASWANDI, M.A., SAFRAN, B., ROZALI, M.B.O. and RIDZWAN, B.H., 1993. Kesan-kesan fisiologi estrak kasar saponin daripada empat spesies imun-laut. In: Prosiding Simposium Sumber Alam Tropika, 1993, Malaysia. Malaysia: UNIMAS, pp. 6-11.

KATANAEV, V.L., DI FALCO, S. and KHOTIMCHENKO, Y., 2019. The anticancer drug discovery potential of marine invertebrates from Russian pacific. Marine Drugs, vol. 17, no. 8, pp. 474-501. http://dx.doi.org/10.3390/md17080474. PMid:31426365.

LAWRENCE, A.J., HANAFY, A., GABR, M., IBRAHIM, H. and GABALLA, A., 2004. Status of the sea cucumber fishery in the Red Sea-the Egyptian experience. In: A. LOVATELLI, C. CONAND, S. PURCELL, S. UTHICKE, J.F. HAMEL and A. MERCIER, eds. Advances in sea cucumber aquaculture and management. Rome: FAO. FAO Fisheries Technical Paper, no. 463.

LEO, R.F. and PARKER, P.L., 1966. Branched-chain fatty acids in sediments. Science, vol. 152, no. 3722, pp. 649-650. http:// dx.doi.org/10.1126/science.152.3722.649. PMid:17779505.

LIU, F., ZAMORA, L., JEFFS, A. and QUEK, S.Y., 2017. Biochemical composition of the Australasian sea cucumber, Australostichopus 
mollis, from a nutritional point of view. Nutrire, vol. 42, no. 1 , pp. 12. http://dx.doi.org/10.1186/s41110-017-0036-z.

LOVATELLI, A., CONAND, C., PURCELL, S., UTHICKE, S., HAMEL, J.F. and MERCIER, A., 2004. Advances in sea cucumber aquaculture and management. Rome: FAO, pp. 1-24. FAO Fisheries Technical Paper, no. 463.

LUPARELLO, C., RAGONA, D., ASARO, D.M.L., LAZZARA, V., AFFRANCHI, F., CELI, M., ARIZZA, V. and VAZZANA, M., 2019. Cytotoxic potential of the coelomic fluid extracted from the sea cucumber holothuria tubulosa against triple-negative mda-mb231 breast cancer cells. Biology, vol. 8, no. 4, pp. 76-89. http://dx.doi. org/10.3390/biology8040076. PMid:31600896.

MATÉS, J.M., PÉREZ-GÓMEZ, C., NÚÑEZ DE CASTRO, I.N., ASENJO, M. and MÁRQUEZ, J., 2002. Glutamine and its relationship with intracellular redox status, oxidative stress and cell proliferation death. The International Journal of Biochemistry \& Cell Biology, vol. 34, no. 5, pp. 439-458. http://dx.doi.org/10.1016/S13572725(01)00143-1. PMid:11906817.

MONA, M.H., OMRAN, N.E., MANSOOR, M.A. and EL-FAKHARANY, Z.M., 2012. Antischistosomal effect of holothurin extracted from some Egyptian sea cucumbers. Pharmaceutical Biology, vol. 50, no. 9, pp. 1144-1150. http://dx.doi.org/10.3109/13880 209.2012.661741. PMid:22486556.

NIGRELLI, R.F., 1952. The effect of holothurin on fish and mice with sarcoma 180. Zoologica, vol. 37, pp. 89-90.

OMRAN, N.E.E., 2013. Nutritional value of some Egyptian sea cucumbers. African Journal of Biotechnology, vol. 12, no. 35, pp. 5466-5472. http://dx.doi.org/10.5897/AJB2013.13020.

PELLET, P.L. and YOUNG, V.R., 1980. Nutritional evaluation of protein foods. Japan: United Nation University, 162 p. (Food and Nutrition Bulletin).

PHILLIPS, N.W., 1984. Role of different microbes and substrates as potential suppliers of specific, essential nutrients to marine detritivores. Bulletin of Marine Science, vol. 35, no.3, pp. 283-298.

PRESTON, G. 1993. Beche-de-mer. In: A. WRIGHT and L. HILL, eds. Nearshore marine resources of the South Pacific: information for fisheries development and management. Honiara: Forum Fisheries Agency, pp. 371-407.

PURCELL, S.W., 2010. Managing sea cucumber fisheries with an ecosystem approach to managing sea cucumber fisheries. In: A. LOVATELLI, M. VASCONCELLOS and Y. YIMIN, eds. Managing sea cucumber fisheries with an ecosystem approach. Rome: FAO, 157 p. FAO Fisheries and Aquaculture Technical Paper, no. 520.

RAGHUNATHAN, C., SADHUKHAN, K., MONDAL, T., SIVAPERUMAN, C. and VENKATARAMAN, K., 2013. A guide to common echinoderms of Andaman and Nicobar islands. Kolkata, India: Zoological Survey of India, pp. 1-210.

RIDZWAN, B.H., HANITA, M.H., NURZAFIRAH, M., NORSHUHADAA, M.P. and HANIS, Z., 2014. Free fatty acids composition in lipid extracts of several sea cucumbers species from Malaysia. International Journal of Bioscience, Biochemistry, Bioinformatics, vol. 4, no. 3, pp. 204-207. http://dx.doi.org/10.7763/IJBBB.2014. V4.340.

RIDZWAN, B.H., KASWANDI, M.A., AZMAN, Y. and FUAD, M., 1995. Screening for antibacterial agents in three species of sea cucumber from coastal areas of Sabah. General Pharmacology, vol. 26, no. 7, pp. 1539-1543. http://dx.doi.org/10.1016/03063623(95)00041-0. PMid:8690242.

ROMASHINA, N.A., 1983. Marine invertebrates as a source of eicosapentaenoic and other polyenoic acids. Biologiya MoryaMarine Biology, vol. 1, pp. 66-68.

SARGENT, J.R., HOPKINS, C.C.E., SEIRING, J.V. and YOUNGSON, A., 1983. Partial characterization of organic material in surface sediments from Balsfjorden, Northern Norway in relation to its origin and nutritional value for sediment-ingesting animals. Marine Biology, vol. 76, no. 1, pp. 87-94. http://dx.doi. org/10.1007/BF00393059.

SINGH, T., 1980. Air gamat anyone? Nature Malaysiana, vol. 12, no. 2, pp. 26-27.

SUSHCHIK, N.N., GLADYSHEV, M.I., MOSKVICHOVA, A.V., MAKHUTOVA, O.N. and KALACHOVA, G.S., 2003. Comparison of fatty acid composition in major lipid classes of the dominant benthic invertebrates of the Yenisei River. Comparative Biochemistry and Physiology. Part B, Biochemistry \& Molecular Biology, vol. 134, no. 1, pp. 111-122. http://dx.doi.org/10.1016/ S1096-4959(02)00191-4. PMid:12524039.

SVETASHEV, V.I., LEVIN, V.S., CHAM, N.L. and DO, T.N., 1991. Lipid and fatty acid composition of holothurians from tropical and temperate waters. Comparative Biochemistry and Physiology Part B: Comparative Biochemistry, vol. 98, no. 4, pp. 489-494. http://dx.doi.org/10.1016/0305-0491(91)90242-6.

WANG, J.F., GAO, S., WANG, Y.M., MA, Q., REN, B.X. and XUE, C.H., 2009. Effects of Isostichopus fuscus on the lipid metabolism in hepercholesteremic rats. Periodical of Ocean University of China, vol. 39, pp. 228-232.

WEN, J., HU, C. and FAN, S., 2010. Chemical composition and nutritional quality of sea cucumbers. Journal of the Science of Food and Agriculture, vol. 90, no. 14, pp. 2469-2474. http:// dx.doi.org/10.1002/jsfa.4108. PMid:20718029.

YAHYAVI, M., AFKHAMI, M., JAVADI, A., EHSANPOUR, M., KHAZAALI, A. and MOKHLESI, A., 2012. Fatty acid composition in two sea cucumber species, Holothuria scabra and Holothuria leucospilata from Qeshm Island (Persian Gulf). African Journal of Biotechnology, vol. 11, no. 12, pp. 2862-2868.

YAMADERA, W., INAGAWA, K., CHIBA, S., BANNAI, M., TAKAHASHI, M. and NAKAYAMA, K., 2007. Glycine ingestion improves subjective sleep quality in human volunteers, correlating with polysomnographic changes. Sleep and Biological Rhythms, vol. 5, no. 2, pp. 126-131. http://dx.doi.org/10.1111/j.14798425.2007.00262.x.

YAMANOUCHI, T., 1955. On the poisonous substances contained in holothurian. Publications of the Seto Marine Biological Laboratory, vol. 41, no. 2-3, pp. 183-202. http://dx.doi.org/10.5134/174528. 